\title{
Assessing the teaching of nursing physical examination in the context of pediatric semiology*
}

\author{
Avaliando a aprendizagem do exame físico de enfermegem no contexto da semiologia pediátrica \\ Evaluando el aprendizaje del examen físico de enfermería en el contexto de la semiología pediátrica
}

\begin{abstract}
Objectives: To assess how nursing students perform the physical examination of children regarding the use of instruments, the sequence of the procedures and the interaction with patients, and identify the phases of motivation and performance in the learning of this exam. Methods: This is a descriptive study, using forms and observing students attending the course 'Semiology and sign and symptom interpretation' in a nursing undergraduate program in Campo Grande, Mato Grosso do Sul State, Brazil. Results: Most students felt motivated to perform the exam and interacted with the child under examination. By assessing student performance, it was possible to identify the difficulties they face using techniques to collecting data on anthropometric measurements, vital signs, auscultation, palpation, percussion, and inspection. Conclusion: The evaluation instrument was considered effective in allowing students to identify the features distinguishing normal from abnormal patterns in children.
\end{abstract}

Marisa Rufino Ferreira Luizari ${ }^{1}$, Conceição Vieira da Silva Ohara ${ }^{2}$, Ana Lúcia Moraes Horta ${ }^{3}$

Keywords: Physical examination; Pediatric nursing; Education, nursing

\section{RESUMO}

Objetivos: Verificar como alunos de enfermagem realizam o exame físico quanto a utilização do material, a seqüência e a interação com a criança, e analisar as fases da motivação e do desempenho na aprendizagem desse exame. Métodos: Estudo descritivo realizado por meio de observação e de formulários com alunos da disciplina 'Semiologia e semiotécnica' em uma instituição em Campo Grande, MS. Resultados: A maioria dos alunos mostrou-se motivada e manteve interação com a criança. A avaliação do desempenho permitiu identificar as dificuldades encontradas pelos alunos na realização das técnicas de coleta de dados antropométricos, sinais vitais, ausculta, palpação, percussão e inspeção. Conclusão: $\mathrm{O}$ instrumento de avaliação física mostrou-se eficaz para que o aluno identifique as características dos padrões normal e anormal na criança.

Descritores: Exame físico; Enfermagem pediátrica; Educação em enfermagem

\section{RESUMEN}

Objetivos: Verificar cómo realizan los alumnos de enfermería el examen físico en cuanto a la utilización del material, la secuencia y la interacción con el niño, y analizar las fases de la motivación y del desempeño en el aprendizaje de ese examen. Métodos: Se trata de um estudio descriptivo realizado por medio de la observación y de la aplicación de formularios a los alumnos de la disciplina 'Semiología y semiotécnica' en una institución de Campo Grande, MS. Resultados: La mayoría de los alumnos se mostró motivado y mantuvo interacción con el niño. La evaluación del desempeño permitió identificar las dificultades encontradas por los alumnos en la realización de las técnicas de recolección de datos antropométricos, signos vitales, auscultación, palpación, percusión e inspección. Conclusión: El instrumento de evaluación física se mostró eficaz para que el alumno identifique las características de los patrones normal y anormal en el niño.

Descriptores: Examen físico; Enfermería pediátrica; Educación en enfermería

\footnotetext{
* This article was extracted form the Thesis "Physical examination in children: a contribution to the study of nursing semiology". The Nursing Department of the Universidade Federal de São Paulo - UNIFESP-São Paulo (SP), Brazil.

${ }^{1}$ Master in Nursing, Assistant Professor at the Universidade Federal de Mato Grosso do Sul- UFMS-Campo Grande, (MS), Brazil.

${ }^{2}$ PhD, Adjunct Professor of the Universidade Federal de São Paulo - UNIFESP - São Paulo (SP), Brazil.

${ }^{3}$ PhD, Adjunct Professor of the Universidade Federal de São Paulo - UNIFESP - São Paulo (SP), Brazill.
} 


\section{INTRODUCTION}

Our experience as nursing professors has revealed that some students find it difficult to evaluate a child physically. This confirmation led to observations and questions about teaching and to the search for ways that could make it possible for students to deepen their capability of observing and understanding significant findings in a child's physical examination.

The physical examination requires "knowledge, attitude, ability, and practice to recognise signs and symptoms that are relevant to nursing and that express changes in the patients' condition"'(1). Therefore, it is a challenge for the nurse since it implies numerous technical-scientific aspects like establishing an interpersonal relationship with the client $^{(2)}$

As shown in COFEN (Nursing Federal Advice) Resolution $n .^{\circ} 272 / 2002^{(3)}$, the physical examination should be performed to identify signs and symptoms of the patient using inspection, percussion, auscultation, and palpation techniques.

Posso et al. ${ }^{(4)}$ defines semiology as "an investigation and study of the patient's signs and symptoms from a nursing point of view". Brunner and Suddarth ${ }^{(5)}$ consider that inspection, palpation, percussion, and auscultation are basic instruments for the physical examination, complemented by special equipments for a better definition of details. Therefore, there has been insufficient systematic observation when performing the physical examination in nursing care as well as in nursing education.

Teaching contents concerning the physical examination requires knowledge associated with prerequisite subjects, including principles of anatomy, physiology, pathology, biology, microbiology, and control over the basic methods needed to perform this examination ${ }^{(6)}$. In children, nurses must consider the basic approach for the examination, the environment and the instrument used, the interaction with the child and the mother, the child's readiness, and the flexibility in the cephalocaudal sequence, in general starting with a painless procedure ${ }^{(7)}$.

We noticed there is a need for proposing teaching strategies to facilitate the teaching-learning developing, in the student, the ability to observe and recognize the phenomenon implied in the child's examination. Thus, we sought for an educational approach in which the evaluation is seen as an inclusion procedure, appraising the student's previous knowledge. Furthermore, as suggested by Luckesi ${ }^{(8)}$, learning is not considered an end, but as a possibility for making decisions. We agree with this author about the need to use different evaluation techniques and instruments, which, dialectically, do not represent an imposition. Rather, it is a constructive act, in which professors need to become available and welcome students as they are, and thus help them in their professional development process.

Considering the factors that interfere in the process of learning how to physically examine a child in nursing undergraduate courses, we observed the reality in teaching situations in order to better identify the structure of the subject of this examination that guides the student in learning the principles and solving problems concerning the use of materials and the sequence of the methods used in paediatric semiology.

\section{OBJECTIVES}

To verify how the nursing student performs the physical examination in children, in terms of material use, procedure sequence, and patient interaction; and analyse the stages of motivation and development according to the Gagné framework ${ }^{(9)}$, concerning the theoreticalpractical teaching of the physical examination in children.

\section{METHODS}

Thirty-six nursing undergraduates too part in this study. The students were attending the "Semiology and semiotechnique" class, which practical activities were developed in two child care units in the city of Campo Grande-MS. After being approved by the Federal University of São Paulo Ethics Committee and receiving permission from the institutions where the data would be collected, the students and the parents of the children participating in the study provided written consent.

Three instruments were used: "The guide to the children's physical evaluation", which was elaborated with elements from the literature and experience of the authors, and pre-tested by three specialists. This instrument has four parts (identification data, anthropometric data, vital signs, and the child's physical exam) covering the basic methods of the examination (inspection, palpation, percussion, and auscultation), as proposed by Christensen ${ }^{(10)}$; “The teachers' observation form about the child's physical examination" was used to evaluate the performance of the nursing student. This form was adapted from the Oliveira's observation model ${ }^{(11)}$, and contains a 10-point scale approaching two ranges: unsatisfactory semiotechnique (less than $80 \%$ of correct measurements) and satisfactory (above $80 \%$ of correct measurements); "The students' form in the teachinglearning process about the child's physical examination" (semi-structured and opened questions).

The data were collected through structured observation from October 1999 to January 2000, after 12 hours of theoretical activities and 24 hours of practical activities with a child population, under the supervision of the teacher. This allowed students to identify the characteristics regarding the children's growth and development, signs 
and symptoms of normality and alterations when performing the physical examination. Each student could choose the patients' age group and received instructions about the children's physical evaluation guide. For the data analysis, the teaching-learning processes were studied regarding the stages of motivation and development according to the Gagné( ${ }^{(9)}$ Learning Theory.

\section{RESULTS}

Most students were girls between 18 and 22 years old. Only $15(41.67 \%)$ had ever look after children before taking this class. For 16 students (44.45\%), teaching refers to the role taken by the teacher in the teachinglearning process; 12 students $(33.33 \%)$ consider that the teacher's role is to facilitate the learning process, by guiding and solving doubts; for eight students $(22.22 \%)$, the teacher's role is to teach as well as to facilitate the learning process. Nearly every student (34, or $94.44 \%$ ) described themselves as motivated during the theoreticalpractical teaching of the examination. The two disencouraged students $(5.56 \%)$ claimed that it was due to tiredness and a great initial difficulty to approach the child and get her to cooperate and perform the physical examination according to her stage of development. Thirty-four students $(94.44 \%)$ considered the instrument of physical evaluation efficient in identifying the characteristics of the normal and abnormal standards in the child, which supported their interventions. Every student interacted with the examined child, especially when they allowed the child to manipulate the examination instruments (stethoscope, otoscope and lantern), or when they explained the procedure or asked for the child's help. The students used this approach in a creative way.

Twenty-three students (63.89\%) used the materials satisfactorily. The other students did not put together most of the necessary materials before the examination, which shows lack of appropriate planning. Putting the material together before the examination facilitates dynamics and, especially, promotes child safety because it avoids the need for the examiner to move away from the child when he or she is on the examination bed. Twenty-nine $(80.56 \%)$ students successfully tested the otoscope and the lantern before the examination, but only four $(11.11 \%)$ warmed the stethoscope as recommended ${ }^{(7,12)}$ to avoid discomfort as well as changes to vital sign parameters, like heart rate.

Twenty-seven $(79.41 \%)$ students followed the examination sequence successfully who started by the cephalocaudal direction, leaving the areas which cause more physical discomfort (ears, mouth, abdomen, painful areas) for last. The remaining students altered the order, beginning with the mouth and oropharynx or by the middle ear, causing more resistance in the child. Two students did not accomplish the exam. The literature points out that pre-scholars are a bigger challenge among the whole paediatric age group, and that evaluating the middle ear is an unavoidable obstacle even when it is left for last. in general, three and four year-olds have developed verbal and cognitive capabilities, and are thus agreeable to being apart from their parents and more motivated to integrate the limitation context. For children over five years of age, the cephalocaudal sequence is generally welcomed ${ }^{(13)}$. Although it is not possible to outline fixed rules for the examination, it is recommended to begin with the child standing, then sitting down, and, only later, when the child becomes more comfortable, he or she can be examined lying down, because the decumbent position can increase the sensation of insecurity ${ }^{(14)}$.

When collecting anthropometric data, the height measurements were more unsatisfactory than those for weight, and thoracic and cephalic perimeters. Twelve $(34.29 \%$ ) out of 35 students (one student did not check the height) did not perform satisfactory measurements, since they did not ask for another person's assistance when measuring children younger than five years of age (what prevented the head and feet from touching the ruler) or not asking children older than five to keep their feet together, the spine straight, arms along the body and the head in an anatomic position.

During height measurements, most students $(65.71 \%)$ acted with agreement with scientific principals: children under three should have their shoes taken off, as well as socks and hair ornaments that could interfere in the measurement. The child should be put in dorsal position; keep the ruler in horizontal position; asking the mother or another person to help holding the child's position so as to keep his or her head straight while the examiner firms the child's knees with one hand keeping the legs in extension and, with the other hand, positions the cursor from the movable part of the ruler, touching firmly the sole of the child's feet, in a straight angle with the movable part ${ }^{(15)}$.

Only five $(13.89 \%)$ out of 36 students performed satisfactory heart rate measurements. Twenty $(68.97 \%)$ out of 29 students made successful blood pressure measurements (only in children older than two). Thirtyone students $(86.11 \%)$ did not verify the heart rate satisfactorily, not finding the apical focus from the point of maximum impulse or not finding the apical or mitral focus by palpation in relation to Louis angle and to the spine, in the left intercostals spaces (LIS).

In infants, this focus is generally situated on the third LIS; in pre-scholars, on the fourth LIS; in scholars on the fifth, from the palpation of the Louis angle and in relation to the point of the imaginary line of the thorax 
on the left hemi-clavicle line ${ }^{(16)}$. The nine students $(31.03 \%)$ who did not proceeded satisfactorily when measuring the blood pressure, did not position the child's arm abreast of the heart and repeated the verification right way, without emptying the inflatable cuff chamber completely or did not select its width properly, or, yet, did not find nor accurately palpate the brachial artery.

Although some health care services do not check children's blood pressure, it should be integrated to children's examinations to avoid future complications ${ }^{(17)}$. This evaluation should be performed on the right arm using a calibrated manometer with the stethoscope on the brachial pulse, two centimetres under the cuff, which width must be proportional to the child's arm $(40 \%$ of the perimeter or $2 / 3$ of the arms length). The chamber must be insufflated at about $30 \mathrm{mmHg}$ above the expected blood pressure for the age, opening the valve slowly and registering the systolic and diastolic pressure ${ }^{(17-18)}$.

Most students performed a proper examination of the children's body segments. Besides being the first basic method of the physical examination, it is also considered the most useful, since most information is collected by direct visualization, or, in some parts of the body, with special instruments, of which the otoscope is the most difficult to learn ${ }^{(19)}$. Most students (22, or $64.70 \%$ ) proceeded unsatisfactorily to the inspection of the mediate ear without asking another person's assistance and without accomplishing the correct contention of the child. The other segments most unsatisfactorily inspected were the ear, the mouth, the oropharynx, and the abdomen.

The segment in which the palpation was less satisfactory was the thorax. Only $12(34.29 \%)$ out of 35 students, proceeded correctly, palpating the thorax bilaterally, with warm fingertips, in the posterior, lateral, and anterior regions. Students who did not perform the examination satisfactorily ( 23 or $65.71 \%$ ) did not warm up their fingertips, did not do it bilaterally and/or omitted the posterior region, different from what is recommended ${ }^{(7,16)}$.

In the percussion, performance in the abdominal examination was better (14 students or $40 \%$ out of 35 ) than in the thoracic. The 21 students $(60 \%)$ who did not perform the exam satisfactorily did not examine all the regions, mainly the posterior. They did not perform the bilateral comparison from top to bottom, kept more than one finger (plessimeter) in contact with the child's thorax, did not re-examine the region to facilitate the sound interpretation and/or did not perform the bilateral examination on the posterior region of the thorax. The examination can be performed directly, with different procedures: on the digit-digital it is used the third right finger (the plessor) arch-shaped, and the examination is performed with the third left finger (the plessimeter) applied on the thorax ${ }^{(20)}$.

As for the auscultation, the thoracic region was performed with more difficulty than the abdominal: only 10 students $(28.57 \%$ ), out of 35 , proceeded satisfactorily. students who did not properly perform the auscultation (25 or $71.43 \%$ ) did not find the points of reference from the spine and the hemi-clavicle line and/or did not perform the auscultation on all thoracic regions ${ }^{(7,16)}$. For the thoracic auscultation, the infants are usually examined in the decubitus position or on the mother's lap; pre-scholars and scholars can be examined sitting down or standing. In both cases, the topographic regions have to be found accurately, without omitting any of the regions, and performing the auscultation in every cardiac focus ${ }^{(21)}$.

\section{DISCUSSION}

The prevalent age group (18 to 22 years old) and gender (female) of the subjects were in agreement with the study by Meyer ${ }^{(22)}$. The fact that only the minority (15 or $41.67 \%$ ) had already taken care of children is important, since the students' young age of the student and inexperience in patient interferes on their learning process $^{(1,23)}$.

The student's perception about the teacher's role in the educational process agrees with the concepts proposed by Gagné( ${ }^{(9)}$ and Rogers ${ }^{(24)}$, who consider that it is the teacher's role to guide and facilitate the learning process, offering the students the opportunity and the conditions to observe the world from many angles, as well as to get to know the different perceptions of the world. Understanding the student's point in the process, identifying the learning aspects that have not yet been covered guarantees an individual reorganization of the learning processes.

Creating conditions to trigger the students' reflection about their own development process, allowing their perception of themselves as subject of their development implies the teacher should know how the student participates in the teaching-learning process of the child's physical examination. Twenty-one students (58.33\%) described themselves as dependent on the teacher, confirming the need of guidance in the physical examination technique because it was their first experience with children.

Fifteen students (41.67\%) described themselves as subjects in the teaching-learning process, justifying that learning depends on their own will and interest, which are essential for the teacher to get the student involved. These findings are in agreement with Gagné( ${ }^{(9)}$, who affirms that a person is naturally active and that learning occurs due to this factor, and also with Freire ${ }^{(25)}$, who states that both teacher and student are subjects in the 
process. For the students to perform the examination satisfactorily, it is necessary to facilitate the development of their ability to observe and perceive the phenomena involved in examining the child and motivate them by promoting an expectation, showing what is expected from them as a consequence of learning and the construction of a body of knowledge necessary for this practice.

The fact that most students (34 or 94.4\%) reported being motivated during the theoretical-practical teaching of the physical examination agrees with Gagné(9), who proposed that the will to learn, associated with the knowledge already detained by the student, promotes their learning, since motivation is associated with the activation, maintenance and direction of their interest, which is added to their previous experiences.

Motivation can be triggered by the expectation of reaching a pre-established goal involving the teacher and the student. Although expectation alone does not guarantee the learning acquisition, it can motivate the students allied with the theoretical contents and strategies suitable to the learning situation. Even the few students who attributed their lack of motivation to their tiredness and the initial difficulty to apply the technique were able, in the end of the process, to achieve greater success on the task, which brought them motivation. The student's perception of something not only involves their motivation or interest by assigning a meaning to what is observed, but also involves a sequence of cognitive activities that include attention, awareness and memory besides the pertinent physiologic capabilities ${ }^{(26)}$. The process of learning this examination can be seen as the result of a process that is not limited to the moment of formal instruction, but it includes experiences that will have strong influence in their professional life. According to the literature, the students' lack of clinical or practical experience of observation can be gradually overcome during the practical activities.

\section{REFERENCES}

1. Laganá MTC, Takito C, Pimenta CAM, Meneghin P, Araújo TL, Faro ACM; Ciclo de Debates sobre a Sistematização do Exame Físico pelo Enfermeiro. Exame físico de enfermagem. Visão dos docentes de fundamentos de enfermagem I e experiência com alunos de graduação. In: Anais São Paulo: Escola Paulista de Medicina Departamento de Enfermagem; 1990. São Paulo: Escola Paulista de Medicina-Depto de Enfermagem; 1990. p. 4960.

2. Santiago LC, Silva ALAC, Tonini T. Semiologia: teorias e tecnologias do/no cuidado com o corpo. In: Santos I, Figueiredo NMA, Duarte MJRS, Sobral VRS, Marinho AM. Enfermagem fundamental: realidade, questões, soluções. Rio de Janeiro: Atheneu; 2001.
Most students (94.44\%) considered the guide for the children's physical examination as efficient to identify the normal and abnormal standards, serving as a support for their interventions and making it possible for them to remember semiology and semiotechnique contents, which made the objectivity in the child's physical examination easier.

The most satisfactory performance evaluation was for body segment inspection. The most difficult learning techniques were height and heart rate measurements, auscultation, thoracic percussion, and abdomen palpation, which require materials and instruments and depend on the the child's collaboration and positioning ${ }^{(7,14)}$.

\section{CONCLUSION}

Most students were women, with 18 to 22 years old (86.11\%), had never taken care of children (58.33\%), and were motivated to learn and perform the children's physical examination $(94.44 \%)$. When examining the regions which caused more physical discomfort in the child, $79.41 \%$ performed the sequence satisfactorily.

The techniques to obtain anthropometric data were apparently easier to learn than those for collecting vital signs. In the examination of body segments, the inspection was the most easily learned method, followed by palpation and percussion.

In search of better ways that contribute to the effectiveness of nursing interventions, it is emphasized the importance of the student's development for performing the children's physical examination. Therefore, it is essential that students be developed continuously, besides obtaining knowledge in other areas, the necessary preliminary techniques, as well as being creative and watching out for the child's aspect, behaviour, and activity, in a way to precisely interpret the findings regarding their growth and development.

3. Conselho Federal de Enfermagem. Resolução COFEN n ${ }^{\circ}$ 272/2002. Art. $1^{\circ}$ : Dispõe sobre a Sistematização da Assistência de Enfermagem - SAE - nas Instituições de Saúde Brasileiras. Rio de Janeiro: COFEN; 2002.

4. Posso MBS, Mohallen AGS, Savonitti BHRS, Sampaio LBN, Chaves LC, Carvalho MHR, et al. Semiologia e semiotécnica de enfermagem. São Paulo: Atheneu; 1999.

5. Brunner LS, Suddarth DS. Avaliação física. In: Smeltzer SC, Bare BG, editores. Brunner \& Suddarth: tratado de enfermagem médico-cirúrgica. $8 \mathrm{a}$ ed. Rio de Janeiro: Guanabara Koogan; 1998.

6. Barros ALBL, Sousa VD, Laubé G, Albertini LF. Análise sobre o ensino do exame físico em escolas de enfermagem da cidade de São Paulo. Acta Paul Enferm. 1997; 10(3):44- 
54.

7. Brêtas JRS, Quirino MD, Silva CV, Sabatés AL, Ribeiro CA, Borba RIH, Almeida FA. Manual de exame físico para a prática da enfermagem em pediatria. São Paulo: Iátria; 2005. p.19-30.

8. Luckesi CC. Avaliação da aprendizagem escolar: estudos e proposições. 12a ed. São Paulo: Cortez; 2002.

9. Gagné RM. Essentials of learning for instruction. New York: Holt, Rinehart \& Winston; 1974.

10. Christensen PJ. Planning priorities, goals, and objetives. In: Griffith-Kenney JW, Christensen PJ, editors. Nursing process: applications of theories, frameworks, and models. 2nd ed. St. Louis: Mosby; 1986.

11. Oliveira ERA. O ensino do exame físico por diferentes estratégias. Ribeirão Preto: Escola de Enfermagem da Universidade de São Paulo; 1998.

12. Rodrigues YT, Rodrigues PPB. Semiologia pediátrica. Rio de Janeiro: Guanabara-Koogan; 1999.

13. Bates B, Hockelman RA. Propedêutica médica. 6a. ed. Rio de Janeiro: Guanabara-Koogan; 1995.

14. Algranati PS. Algranati PS. Effect of developmental status on the approach to physical examination. Pediatr Clin North Am. 1998; 45(1):1-23.

15. Lopez LA, Lopez FA. Medidas antropométricas. In: Rodrigues Y'T, Rodrigues PPB. Semiologia pediátrica. Rio de Janeiro: Guanabara-Koogan; 1999. cap. 5. p. 26-32.

16. Wong DL. Whaley \& Wong: enfermagem pediátrica: elementos essenciais à intervenção efetiva. $5 \mathrm{a}$ ed. Rio de Janeiro: Guanabara-Koogan; c1999.

17. Cabral SA. Aparelho cardiovascular. In: Rodrigues YT,
Rodrigues PPB. Semiologia pediátrica. Rio de Janeiro: Guanabara-Koogan; 1999. p. 134-45.

18. Kakehashi S, Oliveira I, Lamas JLT. Monitorização nãoinvasiva da pressão arterial. In: Chaud MN, Peterlini MAS, Harada MJCS, Pereira SR. O cotidiano da prática de enfermagem pediátrica. São Paulo: Atheneu; 1999. cap. 11.

19. Alexander MM, Brown MS. Diagnóstico na enfermagem pediátrica. São Paulo: Andrei; 1978.

20. Barbosa ADM, Costa SVC, Reis RLR. Ectoscopia. In: Barbosa ADM, et al. Semiologia pediátrica. São Paulo: Byk; 1995.

21. Lima AF, Tortori CFA, Tortori MMRL. Tórax e aparelho respiratório. In: Rodrigues YT, Rodrigues PPB. Semiologia pediátrica. Rio de Janeiro: Guanabara-Koogan; 1999.

22. Meyer DE. A formação da enfermeira na perspectiva do gênero: uma abordagem sócio-histórica. In: Waldow VR, Lopes MJM, Meyer DE. Maneiras de cuidar, maneiras de ensinar: a enfermagem entre a escola e a prática profissional. Porto Alegre: Artes Médicas; 1995.

23. Ângelo M. Vivendo uma prova de fogo: as experiências iniciais da aluna de enfermagem [tese]. São Paulo: Instituto de Psicologia da Universidade de São Paulo; 1989.

24. Rogers C. Liberdade para aprender em nossa década. Porto Alegre: Artes Médicas; 1985.

25. Freire P. Pedagogia do oprimido. 31a ed. Rio de Janeiro: Paz e Terra; 2001. p. 68-86.

26. Matheus MCC, Fugita RMI, Sá AC. Observação em enfermagem. In: Cianciarullo TI. Instrumentos básicos para o cuidar: um desafio para a qualidade de assistência. São Paulo: Atheneu; 1996. p. 5-24. 